\title{
Pengaruh Pendapatan, Pengetahuan Dan Kerentanan Penyakit Terhadap Willingness To Pay (WTP) Premi Jaminan Kesehatan Pada Pekerja Sektor Informal
}

\author{
Anom Dwi Prakoso
}

anomdwiprakoso@gmail.com, Universitas Medika Suherman, Indonesia

\begin{abstract}
Background: The Indonesian Government's target of Universal Coverage or 100\% Health Insurance participation by 2019 failed to be achieved, even until the end of October 2020. The failure of universal coverage resulted in BPJS Health's finances getting worse after experiencing a deficit. Informal sector workers are the most dominant sector that has not participated in the Health Insurance scheme, totaling 30,487,891 workers. Low income, uncertain each month and the increase in contributions resulted in a decrease in Willingness to pay Health Insurance contributions.

Research purposes: The purpose of this study is to analyze the effect of income, knowledge and disease susceptibility to the willingness to pay (WTP) of health insurance contributions to informal sector workers.

Method: This cross-sectional research was conducted in Kudus Regency, Central Java in January-February 2020. Sampling used purposive sampling with a total of 200 informal sector workers who had not yet participated in BPJS Kesehatan. The dependent variable is willingness to pay. The independent variables are income, knowledge and disease susceptibility. Data collection using a questionnaire and data analysis with logistic regression.

Result: Willingness To Pay health insurance contributions for informal sector workers increased in income $\geq R p$ $2,218,451(b=2.02 ; 95 \% C I=1.01-3.55 ; p=0.044)$, high knowledge $(b=4.64 ; 95 \% C I=2.36-8.31 ; p<0.001)$, high disease susceptibility $(b=3.01 ; 95 \% C I=0.26-5.75 ; p=0.031)$.

Conclusion: Income, knowledge and disease vulnerability have a significant effect on the willingness to pay of health insurance contributions for informal sector workers.
\end{abstract}

Key words: Universal Health Coverage; Willingness To Pay; Health Insurance; informal sector workers.
Abstrak kesediaan membayar (willingness to pay) premi Jaminan Kesehatan. dengan regresi logistik. willingness to pay premi Jaminan Kesehatan pada pekerja sektor informal.

Latar belakang: Target Pemerintah Indonesia tentang Cakupan Semesta atau 100\% kepesertaaan Jaminan Kesehatan pada tahun 2019 gagal tercapai, bahkan sampai akhir Oktober 2020. Kegagalan cakupan semesta mengakibatkan Keuangan BPJS Kesehatan semakin terpuruk setelah mengalami defisit. Pekerja sektor informal menjadi sektor paling dominan yang belum mengikuti skema Jaminan Kesehatan sebanyak 30.487.891 pekerja. Pendapatan rendah, tidak pasti tiap bulannya serta ditambah kenaikan premi mengakibatkan menurunnya

Tujuan Penelitian: Tujuan penelitian ini yaitu menganalisis pengaruh pendapatan, pengetahuan dan kerentanan penyakit terhadap willingness to pay (WTP) premi Jaminan Kesehatan pada pekerja sektor informal.

Metode: Penelitian cross sectional dilakukan di Kabupaten Kudus, Jawa Tengah pada bulan Januari-Februari 2020. Pengambilan sampel menggunakan purposive sampling dengan jumlah 200 pekerja sektor informal yang belum menjadi peserta BPJS Kesehatan. Variabel dependen yaitu willingness to pay. Variabel independen yaitu pendapatan, pengetahuan dan kerentanan penyakit. Pengumpulan data menggunakan kuesioner dan analisis data

Hasil: Willingness to pay premi Jaminan Kesehatan pada pekerja sektor informal meningkat pada pendapatan

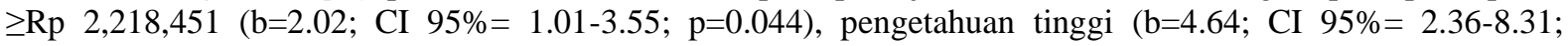
$\mathrm{p}<0.001)$, kerentanan penyakit tinggi $(\mathrm{b}=3.01$; CI 95\% $=0.26-5.75 ; \mathrm{p}=0.031)$.

Kesimpulan: Pendapatan, pengetahuan dan kerentanan penyakit memiliki pengaruh signifikan terhadap

Kata kunci: Cakupan Semesta; Willingness To Pay; Jaminan Kesehatan; pekerja sektor informal.

\begin{tabular}{|l|l|l|}
\hline DOI & $:$ & $\mathbf{1 0 . 2 4 9 0 3 / k u j k m . v 7 i 1 . 1 1 6 6}$ \\
\hline Received & $:$ & November 2020 \\
\hline Accepted & $:$ & November 2020 \\
\hline Published & $:$ & June 2021 \\
\hline
\end{tabular}




\section{Copyright Notice}

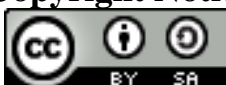

This work is licensed under Creative Commons Attribution 4.0 International License.

P-ISSN: 2477-1880 E-ISSN: 2502-6623

\section{PENDAHULUAN}

Universal Health Coverage (UHC) merupakan salah satu target dari Sustainable Development Goals (SDGs) yang bertujuan untuk mewujudkan terpenuhinya hak akses ke pelayanan kesehatan kepada semua orang, menghindarkan risiko jatuh miskin akibat pengobatan penyakit katastropik dan penyakit dengan tindakan operasi yang membutuhkan finansial tinggi (Hogan et al., 2018). Amanat Pancasila dan UndangUndang Dasar 1945 Pasal 28H ayat 1 dan 3 serta Pasal 34 ayat 1, 2, 3 adalah untuk menjamin kesehatan dan jaminan sosial bagi seluruh warga Negara (Pemerintah Indonesia, 1945). Sebagai tindak lanjut hal tesebut, dibentuklah Sistem Jaminan Sosial Nasional (SJSN) untuk memberikan jaminan terpenuhinya kebutuhan dasar hidup yang layak bagi setiap peserta dan atau anggota keluarganya (Pemerintah Indonesia, 2004).

Sejalan dengan Progam Indonesia Sehat pilar ketiga yaitu Jaminan Kesehatan yang bersifat wajib dan mencakup seluruh penduduk Indonesia, maka dibentuk suatu badan hukum yang diberi nama Badan Penyelenggara Jaminan Sosial (BPJS) pada tahun 2013. BPJS merupakan bentuk tindak lanjut dari SJSN yang berfungsi menyelenggarakan program jaminan kesehatan. Jaminan kesehatan menggunakan prinsip asuransi sosial yaitu kepesertaan yang bersifat wajib, besaran premi berdasarkan persentase pendapatan dan semua anggota mendapatkan pelayanan kesehatan yang sama (Pemerintah Indonesia, 2004).

Dengan mulai diberlakukannya BPJS kesehatan pada bertepatan pada 1 Januari 2014, maka sesuai intruksi perundangan-undangan setiap Warga Negara Indonesia wajib mendaftarkan diri dan anggota keluarganya pada BPJS Kesehatan. Tetapi, target Pemerintah Indonesia bahwa seluruh warga Negara menjadi peserta BPJS Kesehatan pada tahun 2019 gagal terealisasi. Bahkan sampai dengan akhir Oktober 2020, cakupan kepesertaan masih jauh dari harapan.

Salah satu yang menjadi penyebab adalah banyaknya pekerja yang bergerak di sektor informal yang belum mendaftarkan diri sebagai peserta BPJS karena belum mau dan belum mampu membayar premi secara rutin perbulan untuk dirinya dan keluarganya (Dewan Jaminan Sosial Nasional, 2020). Mengingat laju 
pertambahan penduduk serta angkatan kerja yang demikian besar dibandingkan dengan penciptaan lapangan kerja, sektor informal memegang peranan berarti di Indonesia serta secara nyata menggambarkan taraf ekonomi dan taraf kehidupan sosial sebagian besar rakyat Indonesia dikarenakan mayoritas pekerja di Indonesia bergerak di sektor Informal (Dedy et al., 2019).

Jumlah penduduk Indonesia diperkirakan sekitar 267 juta jiwa. Cakupan kepesertaan Jaminan Kesehatan secara nasional per oktober 2020 mencapai $82.6 \%$ atau 222,435,719 jiwa. Artinya masih terdapat sekitar 45 juta jiwa yang belum mendaftarkan diri ke BPJS Kesehatan. Dilaporkan oleh Dewan Jaminan Sosial Nasional (DJSN) terdapat pertumbuhan negatif dari jumlah kepesertaan tahun sebelumnya yaitu sejumlah -214,163 jiwa serta sebanyak 25,054,532 jiwa status kepesertanyaannya tidak aktif.

Berdasarkan data Badan Pusat Statistik, (2020), total jumlah pekerja sektor informal di Indonesia 70.49 juta jiwa. Sedangkan menurut DJSN, jumlah pekerja di sektor informal atau Pekerja Bukan Penerima Upah (PBPU) yang tidak masuk dalam skema PBI sejumlah 30.487.891. Artinya sebanyak $53.1 \%$ atau sejumlah 16,193,597 pekerja sektor informal tidak aktif membayar premi (Dewan Jaminan Sosial Nasional, 2020).

Menurut data DJSN, Jumlah kepesertaan progam JKN per agustus 2020 di Jawa Tengah mencapai $81.87 \%$ dengan $28,642,960$ jiwa dari total jumlah penduduk sejumlah 34,940,078 jiwa. Artinya, terdapat $6,297,118$ penduduk yang belum terdaftar sebagai peserta di BPJS Kesehatan. Sektor informal masih menjadi yang paling dominan belum terdaftar sebagai peserta BPJS Kesehatan.

Sebanyak 10.52 juta orang (58.49 $\%$ ) penduduk bekerja pada sektor informal. Diketahui dari total pekerja sektor informal di Jawa Tegah, hanya 3,802,209 (36\%) pekerja informal yang sudah terdaftar menjadi peserta BPJS Kesehatan (Badan Pusat Statistik Provinsi Jawa Tengah, 2020; Dewan Jaminan Sosial Nasional, 2020).

Berdasarkan data BPS Kabupaten Kudus didukung hasil survei awal yang diperoleh dari BPJS Kesehatan Kabupaten Kudus, sebanyak 827,911 jiwa dari total penduduk sekitar 877,920 jiwa sudah terdaftar sebagai peserta Jaminan Kesehatan. Artinya terdapat sekitar 50,000 jiwa belum berpartisipasi pada progam Jaminan Kesehatan. Diketahui jumlah pekerja sektor informal yang belum mengikuti progam jaminan kesehatan sejumlah 31,127 orang. Sedangkan total pekerja sektor informal di Kabupaten 
Kudus sejumlah 81,531 orang. (Badan

Pusat Statistik Kabupaten Kudus, 2018;

BPJS Kesehatan Kantor Cabang Kudus, 2019).

Tabel 1 Perubahan Tarif Iuran Jaminan

Kesehatan bagi Peserta Pekerja Bukan Penerima Upah (PBPU) dan Bukan Pekerja (BP)

\begin{tabular}{llll}
\hline Peraturan & Presiden & Peraturan & Presiden
\end{tabular}

Nomor 82 Tahun 2018 Nomor 64 Tahun 2020

\begin{tabular}{ll}
\hline Kelas I: $\operatorname{Rp~80,000}$ & Kelas I: Rp 160,000 \\
\hline Kelas II: Rp 51,000 & Kelas II: Rp 110,000 \\
\hline
\end{tabular}

Kelas III: Rp 25,500 Kelas III: Rp 42,000

Berdasarkan tabel perubahan tarif iuran jaminan kesehatan diatas, dapat diketahui bahwa tarif BPJS Kesehatan mengalami kenaikan signifikan di setiap manfaat pelayanan di semua kelas ruang perawatan. Pada kelas I mengalami kenaikan sebesar Rp 80,000 atau 100\%, kelas II mengalami kenaikan 59,000 atau $115 \%$, dan kelas III sebesar 16,500. Tetapi besaran iuran di ruang perawatan kelas III sejumlah 16,500 ditanggung oleh Pemerintah Pusat sebagai bantuan iuran kepada peserta PBPU dan BP sesuai yang tertera di pasal 34 ayat 1,2,3 pada Peraturan Presiden Nomor 64 Tahun 2020. Hal ini berarti tarif iuran jaminan kesehatan yang dibayarkan peserta untuk kelas III tetap yaitu sejumlah Rp 25,500.

Biaya yang dikeluarkan untuk investasi kesehatan dalam hal ini yaitu biaya iuran Jaminan Kesehatan per bulan menjadi beban tambahan bagi pekerja sektor informal dengan pendapatan rendah dan tidak pasti tiap bulannya. Banyak pekerja yang tergolong rentan miskin dengan pendapatan harian minim tetapi tidak tercover dalam skema Penerima Bantuan Iuran (PBI). Hal ini menjadi salah satu penyebab mengapa pekerja di sektor informal banyak yang belum mau mendaftar sebagai peserta BPJS Kesehatann dan belum mau jika diharuskan untuk membayar premi sebesar Rp 25,000 per bulan secara rutin.

Banyaknya pekerja sektor informal yang belum menjadi peserta BPJS Kesehatan menjadi salah satu penyebab tidak berjalannya subsidi silang antara orang sehat kepada orang sakit dan memperburuk keuangan BPJS Kesehatan yang mengalami defisit anggaran. Tingginya keengganan pekerja informal untuk mendaftarkan diri sebagai peserta BPJS Kesehatan dikarenakan belum memiliki kemamuan membayar (willingness to pay) premi secara rutin diantaranya dipengaruhi oleh pendapatan, pengetahuan dan kerentanan penyakit dari pekerja informal.

Menurut penelitian Aryani \& Muqorrobin, (2013) menyatakan bahwa pendapatan berpengaruh positif terhadap willingness to pay iuran peserta BPJS Kesehatan Kelas III untuk peningkatan pelayanan kesehatan. Semakin tinggi pendapatan seseorang, maka tingkat 
harapan mendapatkan pelayanan yang baik akan meningkat juga sehingga membayar tambahan untuk peningkatan pelayanan kesehatan.

Berdasarkan penelitian Kado et al., (2020) Pengetahuan yang baik tentang CBHI (Community-Based Health Insurance) memiliki pengaruh yang signifikan terhadap kesediaan untuk membayar iuran skema Asuransi Kesehatan Berbasis Komunitas Pedesaan di Distrik Gemmachis, Ethiopia Timur.

Status kesehatan seseorang memengaruhi kesediaan untuk membayar

\section{METODE}

\section{Desain Penelitian}

Desain penelitian yang digunakan adalah analitik observasional dengan pendekatan cross sectional. Penelitian dilaksanakan di Kabupaten Kudus, Jawa tengah pada Januari-Februari 2020.

\section{Populasi dan Sampel}

Populasi yang digunakan dalam subjek penelitian ini yaitu semua pekerja sektor informal yang belum menjadi peserta BPJS Kesehatan di Kabupaten Kudus sejumlah 31,127 orang. Adapun jumlah sampel yang digunakan adalah 200 pekerja sektor informal yang belum menjadi peserta BPJS Kesehatan di Kabupaten Kudus. Teknik pengambilan sampel menggunakan purposive sampling.

3. Variabel Penelitian perawatan kesehatan swasta di China. Orang yang merasa status kesehatannya semakin kurang karena semakin tua, semakin besar tingkat pendaftarannya dan semakin tinggi pula kesediaan untuk membayar perawatan kesehatan (Wang, 2019).

Berdasarkan paparan data diatas, tujuan dari penelitian ini adalah menganalisis pengaruh pendapatan, pengetahuan dan kerentanan penyakit terhadap willingness to pay (WTP) premi Jaminan Kesehatan pada pekerja sektor informal.

Variabel dependen dalam penelitian ini adalah kemauan membayar (willingness to pay). Sedangkan variabel independen dalam penelitian ini adalah pengetahuan, pendapatan, dan kerentanan penyakit.

4. Definisi Operasional Variabel

Pendapatan adalah upah rata-rata yang diterima subjek penelitian setelah bekerja dalam kurun waktu satu bulan pada saat bulan penelitian. Alat ukur yang digunakan adalah kuesioner. Kode $1=$ Tinggi $(\geq R p$ 2,218,451), $0=$ Rendah $(<\operatorname{Rp} 2,218,451)$. Pengetahuan adalah segala sesuatu berkaitan informasi berkaitan dengan jaminan kesehatan nasional yang diketahui dan disadari. Alat ukur yang digunakan kuesioner. Skala data kontinu, untuk keperluan analisis data diubah menjadi 
dikotomi. Kode 1 (tinggi) jika skor $\geq$ Mean/

Median, kode 0 (rendah) jika skor <Mean/

Median.

Kerentanan penyakit adalah penilaian positif atau negatif individu tentang risiko untuk sakit dan menderita sakit. Alat ukur yang digunakan kuesioner. Skala data kontinu, untuk keperluan analisis data diubah menjadi dikotomi. Kode 1 (tinggi) jika skor $\geq$ Mean/ Median, kode 0 (rendah) jika skor $<$ Mean/ Median.

Willingness to pay adalah kemauan pekerja sektor informal membayar premi BPJS kelas III sebesar Rp 25,500 secara rutin tiap bulan. Alat ukur yang digunakan kuesioner. Skala data kontinu, untuk keperluan analisis data diubah menjadi dikotomi. Kode 1 Mau membayar ( Rp 25,500), kode 0 Belum mau membayar $(<\operatorname{Rp} 25,500)$.

\section{Analisis Data}

\section{Analisis Univariat}

Deskripsi variabel penelitian secara univariat distribusi subjek penelitian berdasarkan masing-masing variabel penelitian.
Analisis univariat menjelaskan tentang gambaran umum data penelitian dan dilakukan pada masing-masing variabel penelitian, yaitu: pengetahuan, pendapatan, dan persepsi kerentanan, didiskripsikan dalam $\mathrm{n}$ dan $\%$.

Analisis bivariat digunakan untuk mengetahui pengaruh masing-masing variabel independen (pengetahuan, pendapatan, dan persepsi kerentanan) terhadap variabel dependen (kemauan membayar/ willingness to pay). Uji statistik chi-square dan perhitungan odds ratio (OR) dengan tingkat kepercayaan/ confident interval (CI) sebesar 95\%.

Analisis multivariat digunakan untuk melihat pengaruh lebih dari satu variabel independen. Metode yang digunakan pada penelitian ini adalah analisis regresi logistik dengan menggunakan Stata 13.

\section{HASIL}




\begin{tabular}{|c|c|c|}
\hline Variabel & $\begin{array}{l}\text { Frekue } \\
\text { nsi (n) }\end{array}$ & $\begin{array}{l}\text { Persentase } \\
(\%)\end{array}$ \\
\hline \multicolumn{3}{|l|}{ Pendapatan } \\
\hline Rendah & 95 & 47.5 \\
\hline $2,218,451)$ & 105 & 52.5 \\
\hline \multicolumn{3}{|l|}{ Tinggi ( $\geq \operatorname{Rp} 2,218,451)$} \\
\hline \multicolumn{3}{|l|}{ Pengetahuan } \\
\hline Rendah & 80 & 40.0 \\
\hline Tinggi & 120 & 60.0 \\
\hline \multicolumn{3}{|l|}{ Persepsi kerentanan } \\
\hline Rendah & 84 & 42.0 \\
\hline Tinggi & 116 & 58.0 \\
\hline Willingnes To Pay & & \\
\hline$(\boldsymbol{W T P})$ & 83 & 41.5 \\
\hline $\begin{array}{l}\text { Mau Membayar (Rp } \\
25,500)\end{array}$ & 117 & 58.5 \\
\hline $\begin{array}{l}\text { Belum Mau Membayar } \\
(<\operatorname{Rp} 25,500)\end{array}$ & & \\
\hline
\end{tabular}

Berdasarkan Tabel 1 menunjukkan bahwa pekerja sektor informal yang berpendapatan rendah (kurang dari Upah Minimum Kota (UMK) Kabupaten Kudus atau $(<\operatorname{Rp} 2,218,451)$ sebanyak 95 orang (47.5\%), sedangkan pekerja sektor informal yang berpendapatan tinggi (lebih dari Upah Minimum Kota (UMK) Kabupaten Kudus atau $<\operatorname{Rp} 2,218,451)$ sebanyak 105 orang $(52.5 \%)$.
Pekerja sektor informal dengan pengetahuan rendah sebanyak 80 (40.0\%), sedangkan pekerja sektor informal yang berpengetahuan tinggi sebanyak 120 $(60.0 \%)$.

Pekerja sektor informal dengan kerentanan penyakit terhadap penyakitnya rendah sebanyak 84 (42.0\%), sedangkan pekerja sektor informal dengan kerentanan penyakitterhadap penyakitnya tinggi sebanyak 116 (58.0\%).

Pekerja sektor informal yang mau membayar premi Jaminan Kesehatan kelas III (Rp 25,500) sebanyak 83 (41.5\%), sedangkan pekerja sektor informal yang belum mau membayar premi Jaminan Kesehatan kelas III ( $<$ Rp 25,500) sebanyak $117(58.5 \%)$.

\section{Analisis Bivariat}

Analisis secara bivariat menjelaskan tentang pengaruh masing-masing variabel independen terhadap variabel dependen (partisipasi pekerja sektor informal pada progam JKN), metode yang digunakan adalah uji chi-square.

Tabel 3 Analisis bivariat pendapatan, pengetahuan dan kerentanan penyakit terhadap willingness to pay (WTP) premi BPJS Kesehatan kelas III

\begin{tabular}{|c|c|c|c|c|c|c|c|c|}
\hline \multirow{3}{*}{ Variabel Independen } & \multicolumn{4}{|c|}{ willingness to pay } & \multirow{2}{*}{\multicolumn{2}{|c|}{ Total }} & \multirow{3}{*}{ OR } & \multirow{3}{*}{$\mathbf{p}$} \\
\hline & \multicolumn{2}{|c|}{ Mau } & \multicolumn{2}{|c|}{ Belum Mau } & & & & \\
\hline & $\mathbf{N}$ & $\%$ & $\mathbf{N}$ & $\%$ & $\mathbf{N}$ & $\%$ & & \\
\hline \multicolumn{9}{|l|}{ Pendapatan } \\
\hline Rendah $(<\operatorname{Rp} 2,218,451)$ & 46 & 48.4 & 49 & 51.6 & 95 & 100 & 2.22 & 0.005 \\
\hline Tinggi $(\geq \operatorname{Rp} 2,218,451)$ & 71 & 67.6 & 34 & 32.4 & 105 & 100 & & \\
\hline
\end{tabular}




\begin{tabular}{|c|c|c|c|c|c|c|c|c|}
\hline \multicolumn{9}{|c|}{ Pengetahuan } \\
\hline Tinggi & 88 & 73.4 & 32 & 26.6 & 120 & 100 & & \\
\hline \multicolumn{9}{|c|}{ Persepsi Kerentanan } \\
\hline Rendah & 38 & 45.2 & 46 & 54.8 & 84 & 100 & 2.58 & 0.001 \\
\hline
\end{tabular}

Tabel 2 menunjukkan bahwa pekerja sektor informal dengan pendapatan tinggi atau $(\geq \operatorname{Rp} 2,218,451)$ meningkatkan willingness to pay $(\mathrm{OR}=2.22 ; \mathrm{p}=0.005)$. Pekerja sektor informal dengan pengetahuan tinggi meningkatkan willingness to pay $(\mathrm{OR}=$ 4.83; $\mathrm{p}<0.001)$. Pekerja sektor informal dengan kerentanan penyakit tinggi meningkatkan willingness to pay $(\mathrm{OR}=2.58 ; \mathrm{p}=0.001)$.

\section{Analisis Multivariat}

Analisis multivariat digunakan untuk melihat pengaruh lebih dari satu variabel independen. Metode yang digunakan pada penelitian ini adalah analisis regresi logistik.

Tabel 4 Analisis regresi logistik pendapatan, pengetahuan dan kerentanan penyakitterhadap willingness to pay (WTP) premi BPJS Kesehatan kelas III

\begin{tabular}{lllll}
\hline & Koefisien & \multicolumn{2}{c}{ CI 95\% } & \\
\cline { 3 - 4 } Variabel Independen & regresi & Batas & Batas & P \\
& $(\mathbf{b})$ & Bawah & Atas & \\
\hline Pendapatan (tinggi) & 2.02 & 1.01 & 3.55 & 0.044 \\
Pengetahuan (tinggi) & 4.64 & 2.36 & 8.31 & $<0.001$ \\
Kerentanan penyakit (tinggi) & 2.53 & 1.19 & 3.21 & 0.012 \\
$N$ obervasi $=200$ & & & & \\
Log likelihood $=-116.14$ & & & & \\
$\mathrm{p}<0.001$ & & & & \\
\hline
\end{tabular}

Berdasarkan tabel diatas, tinggi dibandingkan yang memiliki pendapatan pekerja sektor informal pendapatan rendah atau <UMK (Rp memiliki pengaruh signifikan terhadap $2,218,451)$ dengan nilai statistik $(b=2.02$; willingness to pay/ kemauan membayar premi BPJS Kesehatan kelas III. Pekerja sektor informal dengan pendapatan tinggi atau $\geq \mathrm{UMK} \quad(\mathrm{Rp} 2,218,451)$ memiliki kemungkinan untuk mau membayar premi BPJS Kesehatan kelas III secara rutin sebesar Rp 25,500 sebanyak 2.02 kali lebih CI $95 \%=1.01$ hingga $3.55 ; \mathrm{p}=0.044)$.

Pekerja sektor informal dengan pengetahuan tinggi memiliki kemungkinan untuk mau membayar premi BPJS Kesehatan kelas III secara rutin sebesar Rp 25,500 sebanyak 4.64 kali lebih tinggi dibandingkan yang berpengetahuan rendah. 
Diketahui pengetahuan memiliki pengaruh yang signifikan willingness to pay pada pekerja sektor informal dengan nilai statistik $(b=4.64 ;$ CI 95\% $=2.36$ hingga $8.31 ; \mathrm{p}<0.001)$.

Kerentanan penyakit memiliki pengaruh signifikan terhadap willingness to pay. Pekerja sektor informal dengan kerentanan penyakit tinggi memiliki kemungkinan untuk mau membayar premi BPJS Kesehatan kelas III secara rutin sebesar Rp 25,500 sebanyak 2.53 kali lebih tinggi dibandingkan yang memiliki kerentanan penyakit rendah $(b=2.53$; CI $95 \%=1.19$ hingga $3.21 ; \mathrm{p}=0.012)$.

\section{PEMBAHASAN}

a. Pengaruh pendapatan terhadap willingness to pay (WTP) premi BPJS Kesehatan kelas III

Hasil penelitian ini menunjukkan bahwa pendapatan memiliki pengaruh terhadap willingness to pay premi BPJS Kesehatan kelas III. Pekerja informal yang memiliki pendapatan tinggi atau $\geq \mathrm{Rp}$ 2,218,451 meningkatkan kemungkinan untuk bersedia membayar premi sebesar 25.5000 secara rutin sebesar 2.02 kali lebih tinggi dibandingkan dengan pekerja informal memiliki pendapatan rendah atau $<\operatorname{Rp} 2,218,451$.

Aryani dan Muqorrobin, (2013) menyatakan bahwa tingkat pendapatan mempengaruhi secara positif dan signifikan terhadap willingness to pay BPJS Kesehatan Kelas III terhadap kenaikan mutu pelayanan kesehatan. Bila pemasukan seorang bertambah, maka WTP juga bakal bertambah dengan anggapan aspek lain dianggap konstan (ceteris paribus). Semakin meningkatnya pemasukan seorang, maka harga yang bertambah tidak bakal menjadi beban untuk dirinya sehingga Dia akan lebih rela membayar ekstra iuran untuk kenaikan pelayanan kesehatan.

Sejalan dengan penelitian (Marzuki, et al., (2017) menunjukkan bahwa jika penghasilan yang dapat dihasilkan seseorang rendah, maka orang tersebut lebih memperioritaskan untuk biaya kebutuhan sehari-hari serta mengesampingkan pembayaran iuran pelayanan kesehatan. Minyihun, et al. (2019) menunjukkan jika status kekayaan secara signifikan berhubungan dengan kesediaan untuk membayar asuransi kesehatan pada rumah tangga pedesaan di Distrik Bugna, Ethiopia Timur Laut $(b=$ $5.55 ; 95 \% \mathrm{CI}=4.19$ - 6.90). Rumah tangga yang tergolong status kekayaannya tinggi meningkatkan kesediaan membayar asuransi 5.55 kali lebih tinggi dibandingkan rumah tangga dengan status kekayaan rendah.

$$
\text { Sejalan Thi et al., (2018) }
$$

Pendapatan rumah tangga secara signifikan 
mempengaruhi kesediaan untuk membayar asuransi kesehatan sosial berbasis keluarga untuk pekerja informal di Vietnam. Rumah tangga dengan pendapatan menengah dan tinggi bersedia membayar lebih tinggi biaya premi asuransi kesehatan sosial. Pendapatan rumah tangga bulanan berpengaruh positif dan signifikan secara statistik terhadap WTP dalam penelitian ini. Pekerja informal dengan pendapatan tinggi meningkatkan 0.32 kali lebih tinggi untuk bersedia membayar asuransi kesehatan sosial dibandingkan pendapatan rendah, sedangkan, pendapatan menengah meningkatkan $\quad 0.25 \quad$ kali.Koefisien pendapatan yang positif sesuai dengan teori permintaan dalam ilmu ekonomi bahwa harus ada hubungan positif antara pendapatan dan WTP.

\section{b. Pengaruh pengetahuan terhadap willingness to pay premi BPJS} Kesehatan kelas III

Hasil penelitian ini menunjukkan bahwa pengetahuan memiliki pengaruh terhadap willingness to pay premi BPJS Kesehatan kelas III. Pekerja informal yang memiliki pengetahuan tinggi meningkatkan kemungkinan 2.02 kali lebih tinggi untuk bersedia membayar premi sebesar $\mathrm{Rp}$ 25.500 secara rutin tiap bulan dibandingkan dengan pekerja informal memiliki pengetahuan rendah.
Menurut Myint, (2019) menyatakan bahwa pengetahuan yang baik memiliki pengaruh yang signifikan terhadap kesediaan membayar premi asuransi kesehatan di Myanmar. Lebih dari 90\% sampel SSS (Social Security Scheme) dan $75 \%$ sampel umum dengan pengetahuan baik bersedia membayar premi asuransi kesehatan (p-value 0.001). Penting untuk meningkatkan tingkat pengetahuan semua kelompok populasi untuk memperluas SSS atau memulai skema asuransi kesehatan baru. Bagi penerima manfaat, pengetahuan tentang asuransi kesehatan seperti apa yang dicakup, layanan mana yang gratis, layanan tambahan mana yang mungkin menyebabkan pembayaran langsung, cara mengakses perawatan kesehatan di bawah asuransi, dan layanan mana yang memenuhi syarat.

Pengetahuan dasar tentang prinsipprinsip asuransi memengaruhi kesediaan untuk membayar Community Health Insurance (CHI) di Uganda. Pengetahuan tentang prinsip $\mathrm{CHI}$ berperan positif dalam membentuk rata-rata 0.7 kali lebih tinggi terhadap kesediaan rumah tangga untuk membayar CHI (Biggeri et al., 2018). Kepala rumah tangga yang berpendidikan tinggi memiliki pengetahuan yang lebih baik tentang keuntungan melakukan pembayaran asuransi secara teratur untuk menghindari risiko pengeluaran medis yang 
besar pada saat sakit. (Minyihun et al., 2019).

Pengetahuan yang baik tentang CBHI (Community Based Health Insurance) memiliki pengaruh yang signifikan terhadap kesediaan untuk membayar iuran skema Asuransi Kesehatan Berbasis Komunitas Pedesaan di Distrik Gemmachis, Ethiopia Timur $(\mathrm{OR}=2.3$, 95\% CI: 1.5, 3.6). Partisipan dengan pengetahuan baik meningkatkan kemungkinan 2.3 kali lebih tinggi untuk bersedia membayar iuran $\mathrm{CBHI}$ dibandingkan partisipan dengan pengetahuan kurang (Kado et al., 2020).

\section{c. Pengaruh kerentanan penyakit terhadap willingness to pay (WTP) premi BPJS Kesehatan kelas III}

Hasil penelitian ini menunjukkan bahwa kerentanan penyakit memiliki pengaruh terhadap willingness to pay premi BPJS Kesehatan kelas III. Pekerja informal yang memiliki kerentanan penyakit tinggi meningkatkan kemungkinan 2.02 kali lebih tinggi untuk bersedia membayar premi Rp 25.500 secara rutin tiap bulan dibandingkan dengan pekerja informal memiliki kerentanan penyakit rendah

Status kesehatan seseorang memengaruhi kesediaan untuk membayar perawatan kesehatan swasta di China. Orang yang merasa status kesehatannya semakin kurang karena semakin tua, semakin besar tingkat pendaftarannya dan semakin tinggi pula kesediaan untuk membayar perawatan kesehatan (Wang, 2019).

Minyihun et al., (2019) menyatakan bahwa riwayat sakit dalam 3 bulan terakhir berpengaruh signifikan terhadap WTP asuransi kesehatan berbasis komunitas (CBHI) di Distrik Bugna, Ethiopia Timur Laut $(b=2,52 ; 95 \% \quad C I=1,29-3,75)$. Individu yang merasa perlu menghindari risiko lebih mungkin untuk mendaftar asuransi kesehatan untuk menghindarkan dari pengeluaran yang lebih banyak saat sakit. Diketahui Rumah tangga yang memiliki riwayat sakit dalam rumah tangganya memiliki WTP 2.5 USD lebih banyak dari pada counterfaktual, dengan variabel lain tetap (ceteris paribus).

Sejalan dengan penelitian $\mathrm{He}$, (2017) menunjukkan bahwa risiko sakit memengaruhi warga Hong Kong untuk bersedia berlangganan asuransi kesehatan swasta sukarela dalam ekonomi medis campuran. status kesehatan yang sangat buruk menunjukkan minat yang lebih kuat untuk berlangganan dengan tingkat signifikansi lebih meningkat dibanding status kesehatan baik, sedang bahkan buruk.

Sejalan dengan penelitian Kado et al., (2020) bahwa partisipan yang mempunyai riwayat sakit dalam setahun 
terakhir meningkatkan kemungkinan

kesediaan untuk membayar iuran skema

Asuransi Kesehatan Berbasis Komunitas

Pedesaan di Distrik Gemmachis, Ethiopia

Timur dibandingkan partisipan yang tidak

\section{REFERENSI}

Aryani, M. A., \& Muqorrobin, M. (2013). Determinan Willingness To Pay(Wtp) Iuran Peserta Bpjs Kesehatan. Jurnal Ekonomi Dan Studi Pembangunan, 14(April), 44-57. Retrieved From Https://Media.Neliti.Com/Media/Publ ications/77951-Id-DeterminanWillingness-To-Pay-Wtp-Iuran.Pdf

Badan Pusat Statistik. (2020). Keadaan Ketenagakerjaan Indonesia Februari 2020. Jakarta. Retrieved From Https://Www.Bps.Go.Id/Pressrelease/ Download.Html?Nrbvfeve=Mty3mg $\% 3 \mathrm{~d} \% 3 \mathrm{~d} \&$ Sdfs $=$ Ldjfdifsdjkfahi\&Tw oadfnoarfeauf=Mjaymc0xms0ymsax mjowntownq $\% 3 \mathrm{~d} \% 3 \mathrm{~d}$

Badan Pusat Statistik Kabupaten Kudus. (2018). Kudus Dalam Angka 2018. Retrieved From Https://Kuduskab.Bps.Go.Id/Publicati on/2018/08/16/7812ae46f6b77cf56e2 2b1f5/Kabupaten-Kudus-DalamAngka-2018.Html

Badan Pusat Statistik Provinsi Jawa Tengah. (2020). Keadaan Ketenagakerjaan Provinsi Jawa Tengah Februari 2020. Semarang. Retrieved From Https://Jateng.Bps.Go.Id/Pressrelease /Download.Html?Nrbvfeve=Mtiwna $\% 3 \mathrm{~d} \% 3 \mathrm{~d} \&$ Sdfs $=$ Ldjfdifsdjkfahi $\& \mathrm{Tw}$ oadfnoarfeauf=Mjaymc0xms0ymsax mto0njoznq\%3d\%3d

Biggeri, M., Nannini, M., \& Putoto, G. (2018). Assessing The Feasibility Of Community Health Insurance In Uganda: A Mixed-Methods Exploratory Analysis. Social Science \& Medicine, 03(200), 145-155. Https://Doi.Org/10.1016/J.Socscimed .2018.01.027 memiliki riwayat sakit. Diketahui riwayat sakit dalam setahun terakhir memiliki pengaruh yang signifikan terhadap WTP CBHI di Distrik Gemmachis $(\mathrm{AOR}=3.1$, 95\% CI, 1.9-5.2).

Bpjs Kesehatan Kantor Cabang Kudus. (2019). Data Cakupan Kepesertaan Jaminan Kesehatan Di Kabupaten Kudus Per Oktober 2019. Kudus.

Dedy, I. P., Hardy, K., Luh, N., Ari, G., \& Yudha, N. (2019). Kemauan Dan Kemampuan Membayar ( Ability Willingness To Pay ) Dalam Kepesertaan Jaminan Kesehatan Nasional Pada Sektor Informal Pedagang Pasar Tradisional Di Kota Denpasar 2017 J . Kes-Terpadu Oktober 2018, 2(2), 96-100.

Dewan Jaminan Sosial Nasional. (2020). Cakupan Kepesertaan 2020. Retrieved From

Http://Sismonev.Djsn.Go.Id/Kepesert aan/

He, A. J. (2017). Introducing Voluntary Private Health Insurance In A Mixed Medical Economy: Are Hong Kong Citizens Willing To Subscribe? Bmc Health Services Research, 17(1), 603. Https://Doi.Org/10.1186/S12913017-2559-7

Hogan, D. R., Stevens, G. A., Hosseinpoor, A. R., \& Boerma, T. (2018). Articles Monitoring Universal Health Coverage Within The Sustainable Development Goals: Development And Baseline Data For An Index Of Essential Health Services. The Lancet Global Health, 6(2), E152-E168. Https://Doi.Org/10.1016/S2214$109 \times(17) 30472-2$

Kado, A., Merga, B. T., Adem, H. A., Dessie, Y., \& Geda, B. (2020). Willingness To Pay For CommunityBased Health Insurance Scheme And Associated Factors Among Rural Communities In Gemmachis District, 
Eastern Ethiopia. Clinicoeconomics And Outcomes Research, 23(12), 609618.

Https://Doi.Org/10.2147/Ceor.S2664 97

Marzuki, D. S., Muh. Yusri Abadi, D., Arifin, M. A., Rahmadani, S., \& Fajrin, M. Al. (2017). Analisis Kemampuan Membayar Dan Kemauan Membayar Peserta Pbpu Jkn Di Kecamatan Tamalate Kota Makassar, 102-113.

Minyihun, A., Gebregziabher, M. G., \& Gelaw, Y. A. (2019). Willingness To Pay For Community - Based Health Insurance And Associated Factors Among Rural Households Of Bugna District , Northeast Ethiopia. Bmc Research Notes, 12(1), 1-7. Https://Doi.Org/10.1186/S13104019-4091-9

Myint, C. Y. (2019). Health Insurance In Myanmar: Knowledge, Perceptions, And Preferences Of Social Security Scheme Members And General Adult Population. The International Journal Of Health Planning And Management, 34(01), 346-369.
Https://Doi.Org/10.1002/Hpm.2643

Pemerintah Indonesia. Undang-Undang Dasar Negara Republik Indonesia Tahun 1945. (1945). Retrieved From Http://Jdih.Pom.Go.Id/Uud1945.Pdf

Pemerintah Indonesia. Undang-Undang Republik Indonesia Nomor 40 Tahun 2004 Tentang Sistem Jaminan Sosial Nasional (2004). Retrieved From Http://Www.Jkn.Kemkes.Go.Id/Attac hment/Unduhan/Uu No. 40 Tahun 2004 Tentang Sjsn.Pdf

Thi, N., Nga, T., Fitzgerald, G., \& Dunne, M. P. (2018). Family-Based Social Health Insurance For Informal Workers In Vietnam : Willingness To Pay And Its Determinants. Asia Pacific Journal Of Public Health, 30(6), 512-520. Https://Doi.Org/10.1177/1010539518 799785

Wang, Y. (2019). Status Of Public - Private Partnership Recognition And Willingness To Pay For Private Health Care In China. The International Journal Of Health Planning And Management, 34(02), 1-12. Https://Doi.Org/10.1002/Hpm.2757 